\title{
ASAS RETROAKTIF TERHADAP TINDAK PIDANA TERORISME
}

\author{
${ }^{1}$ Notariani Asril, ${ }^{2}$ Husni, ${ }^{2}$ Ferdy Saputra
}

Email: husni@unimal.ac.id

${ }^{1}$ Mahasiswa Fakultas Hukum, Universitas Malikussaleh
2Dosen Fakultas Hukum Universitas Malikussaleh

\begin{abstract}
This study aims to explain the retroactive principle in the terrorism law and the juridical implications of the decision of the constitutional court number 013/PUUI/2003 related to the retroactive application of the terrorism law. The basic principle of the law adheres to the principle of legality, but in some statutory provisions this principle of legality does not apply retroactively, meaning that it is possible to apply the retroactive principle even if only in certain cases. Retroactive application is permitted if it is in accordance with the provisions in Article 1 paragraph (2) of the Criminal Code. The type of research used is normative juridical which is descriptive by using a statute approach related to extraordinary crimes against terrorism. The results of the study state that the retroactive principle is legislation earlier than when it was promulgated. The law that is applied retroactively (retroactively) changes the legal consequences of the actions taken or the legal status of the actions and relationships that occurred before the enactment of the law. Indonesia must act quickly in responding to the conditions that occur in order to maintain the good name of the country's sovereignty, namely through the establishment of an emergency law. The effort taken by the government is to override the legality principle, so that the law can be applied retroactively to the Bali Bombing I case. This step is taken so that the government has a strong legal basis to be able to ensnare and prosecute the perpetrators.
\end{abstract}

Keyword : retroactive principle, terrorism, extraordinary crime. 


\section{PENDAHULUAN}

Asas legalitas dipandang sebagai asas terpenting dalam hukum pidana Indonesia, sehingga diatur sebagai induk hukum pidana, Ketentuan Pasal 1 ayat (1) KUHP dalam Buku I KUHP tentang Ketentuan Umum. Adanya asas legalitas yang disebutkan dalam Pasal 1 ayat (1) KUHP dalam penegakan hukum dan keadilan sebenarnya merupakan persoalan yang sulit, karena jelas asas legalitas hanya mengenal hukum tertulis. ${ }^{1}$

Ada dua ketentuan terkait asas non-retroaktif atau larangan berlaku surut peraturan perundang-undangan, yaitu Pasal 28 UUD 1945 dan Pasal 1 ayat (1) KUHP. Pasal 1 ayat (1) KUHP dapat disebut dengan asas legalitas, berlakunya asas legalitas dalam tindak pidana memiliki dua akibat yang harus dipatuhi yaitu ketentuan hukum pidana harus tertulis (rumusan sesuai undang) dan ketentuan hukum pidana tidak dapat berlaku surut (retroaktif). ${ }^{2}$

Saiichiro Uno mengemukakan bahwa kejahatan luar biasa merupakan fenomena umum yang mengikuti perkembangan zaman, tidak hanya meningkat secara kuantitas tetapi juga kualitasnya. ${ }^{3}$ Terorisme merupakan tindak pidana yang tergolong dalam kejahatan luar biasa, Indonesia sendiri menyadari bahaya tindak pidana terorisme sehingga pemerintah bekerja keras untuk membuat undang-undang yang secara jelas dapat mengendalikan terorisme. Pemerintah dan masyarakat semakin sadar akan pentingnya undang-undang khusus untuk memberantas terorisme, terutama pasca peristiwa bom di Bali pada 12 Oktober 2002 (bom pertama di Bali). Kasus bom Bali tidak hanya menimbulkan dampak yang sangat besar bagi bangsa Indonesia, tetapi juga mengakibatkan runtuhnya struktur sosial dan ekonomi dalam skala kecil maupun besar.

Indonesia memiliki undang-undang yang khusus menangani terorisme, yaitu Undang-Undang Nomor 5 Tahun 2018 tentang Perubahan atas Undang-Undang Nomor 15 Tahun 2003 tentang Penetapan Peraturan Pemerintah Pengganti Undang-Undang Nomor 1 Tahun 2002 tentang Pemberantasan Tindak Pidana terorisme menjadi Undang-Undang. Peraturan pemerintah yang menggantikan undang-undang dan kemudian disahkan menjadi undang-undang jelas dapat diterapkan secara surut (retroaktif) khususnya dalam kasus bom Bali I.

Pada Peristiwa Peledakan Bom Di Bali Tanggal 12 Oktober 2002 Menjadi Undang-Undang. Dalam pemberlakuannya di Indonesia, undang-undang terorisme tersebut kemudian pernah diajukan tentang uji materinya (judicial review) ke Mahkamah Konstitusi (MK) oleh salah seorang terdakwa dalam peledakan kasus Bom Bali I. Berdasarkan putusan Perkara Nomor 013/PUU-I/2003, Mahkamah Konstitusi kemudian menyetujui permohonan tersebut dan menyatakan bahwa

\footnotetext{
${ }^{1}$ Sri Rahayu, Implikasi Asas Legalitas Terhadap Penerapan Hukum dan Keadilan, Jurnal Inovatif Vol. VII, No.3 (Jambi: Universitas Jambi, 2014), hlm. 7.

2 Masrichin Ruba'i, Asas-Asas Hukum Pidana, (Malang: UM Press, 2001), hlm. 11.

${ }_{3}$ Barda Nawawi Arief, Kebijakan Legislatif dalam penanggulangan Kejahatan dengan Pidana Penjara, (Semarang: Ananta, 1994), hlm. 1.
} 
Undang-Undang Nomor 16 Tahun 2003 melanggar UUD 1945, sehingga undangundang tersebut tidak lagi bersifat permanen dan mengikat. Memang tidak mudah memadukan asas legalitas dengan retroaktif secara seimbang.

sebagai jalan tengah dalam solusi perkembangan kedua asas tersebut guna tetap dapat berjalan secara beriringan, maka ditentukan asas legalitas masih menjadi asas pokok dalam hukum pidana dan sedangkan asas retroaktif hanya terbatas pada kasus-kasus tertentu saja yang dikategorikan sangat membahayakan bagi kepentingan masyarakat.

Tujuan dari penelitian ini untuk mengetahui dan menjelaskan asas retroaktif dalam undang-undang tindak pidana terorisme dan untuk mengetahui serta menjelaskan implikasi yuridis putusan Mahkamah Konstitusi Nomor 013/PUUI/2003 terkait dengan pemberlakuan surut undang-undang terorisme.

\section{METODE PENELITIAN}

Berdasarkan uraian latar belakang di atas, maka rumusan masalah dalam penelitin ini adalah : bagaimanakah asas retroaktif dalam undang-undang tindak pidana terorisme?. bagaimanakah implikasi yuridis putusan Mahkamah Konstitusi Nomor 013/PUU-I/2003 terkait dengan pemberlakuan surut undang-undang terorisme?. Metode penelitian yang digunakan dalam penulisan skripsi ini adalah jenis hukum normatif yang artinya membuat hukum sebagai sebuah pondasi sistem norma, diantaranya asas-asas, kaidah atau peraturan perundangan-undangan, norma hukum, putusan pengadilan, dan perjanjian serta doktrin. ${ }^{4}$ Pendekatan yang digunakan dalam penelitian ini adalah pendekatan menggunakan aturan perundang-undangan (statue approach). Penelitian ini bersifat deskriptif, peneliti dalam melakukan analisis data bertujuan untuk memberikan pemaparan yang jelas atas subjek dan objek penelitian dan memberikan gambaran ataupun kesimpulan sebagaimana hasil penelitian yang dilakukan. ${ }^{5}$ Sumber bahan hukum yang digunakan adalah bahan hukum primer, bahan hukum sekunder, dan bahan hukum tersier. Teknik pengumpulan data yaitu library research.

\section{HASIL PENELITIAN DAN PEMBAHASAN}

\section{Asas Retroaktif dalam Undang-Undang Tindak Pidana Terorisme}

\section{Penegakan Hukum Terhadap Terorisme sebagai Kejahatan Luar Biasa}

Adanya konvensi internasional yang mengatur tentang terorisme menunjukkan bahwa terorisme telah menjadi kejahatan internasional terhadap kemanusiaan, sehingga akhirnya terorisme di atur ke dalam norma internasional dan menjadi hukum kebiasaan internasional. Menyusul Resolusi Dewan Keamanan PBB 1938, pemerintah Indonesia mengeluarkan dua peraturan pemerintah yang

\footnotetext{
${ }^{4}$ A. Fuad Usfa dan Tongat, Pengantar Hukum Pidana, (Malang: UMM Press, 2004), hlm. 9.

5 Sunaryati Hartono, Penelitian Hukum Indonesia pada Akhir ke-20, (Bandung : Alumni, 1994), hlm. 101.
} 
diganti dengan undang-undang di Republik Indonesia pada tanggal 18 Oktober 2002, yaitu:

a. Perppu No. 1 Tahun 2002 tentang Pemberantasan Tindak Pidana Teroris yang tidak berlaku surut

b. Perppu Nomor 2 Tahun 2002 tentang Pemberlakuan Perppu Nomor 1 Tahun 2002 tentang Pemberantasan Tindak Pidana Terorisme pada peristiwa Peledakan Bom Bali tanggal 12 Oktober 2002 yang berlaku surut. 6

Perppu tersebut diberlakukan per tanggal 18 Oktober 2002 dan pada tanggal 4 April 2003 ditetapkan sebagai Undang-Undang Republik Indonesia Nomor 15 dan 16 Tahun 2003 tentang Pemberantasan Tindak Pidana Terorisme. Pemberantasan terorisme berdasar atas komitmen nasional dan dunia internasional dengan melakukan dan membentuk aturan perundang-undangan nasional yang tentunya mengacu pada konvensi internasional yang dilakukan, dan juga mengacu pada undang-undang yang berkaitan dengan terorisme. Apabila dilihat dari asal mula lahirnya Perppu tersebut, maka tragedi bom Bali 12 Oktober 2002 yang dilakukan oleh teroris tentunya menjadi fakta yuridis dan sosiologis bagi pemerintah untuk melakukan tindakan penegakan hukum terhadap terorisme.

Dalam keadaan darurat, beberapa langkah khusus dapat diambil, langkah dan tindakan ini tidak boleh melanggar hukum yang berlaku dan standar hak asasi manusia internasional mengingat adanya beberapa hak fundamental yang tidak dapat dikurangi atau. diabaikan dalam kondisi apapun termasuk jika negara dalam kondisi darurat yang disebut Non-derogable rights.

\section{Asas Retroaktif dalam Undang-Undang Tindak Pidana Terorisme}

Asas retroaktif sendiri merupakan bagian dari asas legalitas yang memuat tiga pengertian, yaitu:

a. Tidak ada perilaku yang tidak diatur dalam peraturan perundangundangan, tidak ada larangan dan hukuman.

b. Untuk menentukan ada tidaknya tindak pidana, analogi (Kias) tidak boleh digunakan.

c. Aturan hukum pidana tidak berlaku surut / non-retroaktif.

Asas Legalitas secara tegas terdapat dalam Pasal 1 ayat (1) KUHP bahwa tidak ada suatu perbuatan dapat ditindak pidana tanpa adanya dasar peraturan undang-undang yang mengaturnya. Perppu mempunyai alasan yang sangat kuat untuk memberlakukan asas rektroaktif dalam memberantas tindak pidana terorisme. Selain dikarenakan terjadinya peristiwa Bom Bali yang terjadi pada 12 Oktober 2002 yang menyebabkan pemerintah mengeluarkan Perppu Nomor 1 Tahun 2002 Tentang Pemberantasan Tindak Pidana Terorisme, tentu dilakukan

6 Mardenis, Pemberantasan Terorisme: Politik Internasional dan Politik Hukum Nasional Indonesia, (Jakarta: PT Raja Grafindo Persada, 2010), hlm. 85-147. 
berlakunya asas retroaktif tersebut, berdalil atas hukum pula. Pasal 22 UndangUndang Dasar Tahun 1945 menegaskan:

a. Dalam hal ihwal kegentingan yang bersifat memaksa, Presiden berhak menetapkan Peraturan Pemerintah sebagai pengganti Undang-undang

b. Peraturan Pemerintah tersebut harus mendapat persetujuan dari Dewan Perwakilan Rakyat dalam persidangan yang berikutnya.

c. Jika tidak mendapat perserujuan, maka Peraturan Pemerintah tersebut harus dicabut.

Asas retroaktif memiliki legitimasi terhadap hukum yang jelas untuk di terapkan. Dapat dijelaskan pula, bahwa terorisme merupakan bagian dari kejahatan terhadap HAM (crimes against humanity), dan juga merupakan kategori extra ordinary crimes, yang bermakna perlu adanya penanganan khusus dalam melakukan tindak pidana terorisme.

\section{IMPLIKASI YURIDIS PUTUSAN MAHKAMAH KONSTITUSI NOMOR 013/PUU- I/2003 TERKAIT DENGAN PEMBERLAKUAN SURUT UNDANG-UNDANG TERORISME}

1. Judicial Review dalam Pemberlakuan Surut Undang-Undang Nomor 15 Tahun 2003

Keputusan Mahkamah Konstitusi, khususnya yang terkait kasus judicial review, bersifat deklaratif pokok yang artinya jika satu-satunya keputusan untuk mempublikasikan adalah untuk menyatakan dan mengulangi apa itu hukum dan pada saat yang sama hal itu menyangkal atau menciptakan situasi hukum lebih baru dari sebelumnya. Salah satunya di lihat dari putusan Mahkamah Konstitusi Nomor 013/ PUU-I / 2003.

Bom Bali I mempengaruhi perkembangan hukum di masa depan dan tidak kecuali pelaku bom Bali sendiri. Sebagai negara yang menganut supremasi hukum, tentu saja putusan Mahkamah Konstitusi (MK) sangat kuat ini memiliki arti penting dalam hukum dan politik Indonesia. Perppu Nomor 1 Tahun 2002 yang telah disahkan menjadi Undang-Undang Nomor 15 Tahun 2003 bisa saja tidak akan memiliki pengaruh apapun pasca diundangkan, apabila seandainya tidak mempunyai keistimewaan khusus untuk di berlakukan secara surut. Karena Pasal 46 dengan jelas mengatur bahwa meskipun bom diledakkan, tidak ada aturan yang mengaturnya, namun pelaku Bom Bali I juga dapat dikenakan sanksi atas perbuatannya.

Tindakan represif yang dilakukan pemerintah Indonesia untuk memberantas terorisme pasca bom Bali tampaknya bertentangan dengan prinsip pidana yang dianut dalam Pasal 1 ayat (1) KUHP. Namun satu hal yang mungkin terlewatkan oleh pemerintah adalah untuk mencapai kepastian hukum, ancaman kepastian keadilan merupakan akibat logis dari transaksi politik yang sah tersebut. Keadilan siapa yang diancam? Tentunya dari sudut pandang pelaku bom Bali sendiri, 
meskipun melakukan tindak pidana, tetap harus diperlakukan sesuai dengan hak asasi mereka, seperti dianggap tidak bersalah sebelum putusan pengadilan memiliki kekuatan hukum yang tetap.

Ketidakpastian sebuah keadilan sebagai akibat adanya kepastian hukum menjadikan para pelaku Bom Bali I berani melakukan perlawanan terhadap negara melalui permohonan pengujian undang-undang yang memberlakukan surut Pasal 46 UU Nomor 15 Tahun 2003, yaitu pengujian atas UU Nomor 16 Tahun 2003.

Masykur Abdul Kadir, salah satu terdakwa kasus Bom Bali I, saat itu melakukan permohonan judicial review terhadap Undang-Undang Nomor 16 Tahun 2003 Tentang Penerapan Perppu Nomor 2 Tahun 2002 Tentang Pemberlakuan Perppu Nomor 1 Tahun 2002 ke Mahkamah Konstitusi. Terdakwa dijatuhi hukuman 15 tahun penjara dalam keputusan yang dikeluarkan oleh Mahkamah Agung.

Melalui putusan nomor 013/ PUU-I/ 2003 yang dibacakan pada hari Jumat, 23 Juli 2004, Mahkamah Konstitusi pada akhirnya menyatakan untuk mengizinkan melakukan permohonan judicial review terhadap Undang-undang Nomor 16 Tahun 2003 Tentang Penerapan Perppu Nomor 2 Tahun 2002 Tentang Pemberlakuan Perppu Nomor 1 Tahun 2002. Sehingga dalam amar putusannya Mahkamah Konstitusi menyatakan, bahwa Undang-undang Nomor 16 Tahun 2003 bertentangan dengan UUD 1945 dan karenanya tidak mempunyai kekuatan hukum mengikat.

Namun, putusan Mahkamah Konstitusi tidak disahkan dengan suara bulat, karena lima hakim menyetujui permohonan peninjauan kembali, sedangkan empat hakim lainnya menolak permohonan dan menyatakan keberatan. Keseluruhan proses hukum di atas menunjukkan bahwa UU Terorisme pada awalnya ditujukan untuk menghukum pelaku bom Bali khusus dengan menjadikannya sasaran hukum pidana. Dapat dikatakan bahwa Undang-Undang Nomor 2 Tahun 2002 dan Undang-Undang Nomor 16 Tahun 2003 merupakan ketentuan yang secara alamiah telah dihapuskan karena telah mengalami cacat legal formal sejak awal.

2. Akibat Hukum Pemidanaan Dan Upaya Perlindungan Hak Asasi Dalam Putusan Mahkamah Konstitusi Nomor 013/PUU-I/2003

Asas retroaktif berlaku terhadap para pelaku bom Bali I di perlihatkan secara tegas yang sekalipun Mahkamah Konstitusi termasuk ke dalam lingkup kekuasaan trias politica akan tetapi mampu menunjukkan independensinya sebagai lembaga kekuasaan kehakiman yang bebas. Pembuktian Mahkamah Konstitusi diumumkan dengan keberanian menyatakan bahwa Undang-Undang Nomor 15 Tahun 2003 tidak lagi dapat diberlakukan secara surut karena Undnag-Undang Nomor 16 Tahun 2003 yang menunjang asas retroakitf dalam Pasal 46 UU Nomor 15 Tahun 2003 dianggap telah bertentangan secara konstitusi dan karenanya tidak lagi mempunyai kekuatan hukum yang mengikat. 
Mahkamah Konstitusi berkeyakinan bahwa sekalipun seseorang jelas-jelas bersalah, ia tetap memiliki status dan hak yang sama di hadapan hukum, termasuk hak untuk dituntut berlaku surut. Mahkamah Konstitusi mengambil keputusan, segala bentuk pemeriksaan yang dilakukan oleh peradilan umum terdahulu, baik di Pengadilan Negeri atau Pengadilan Tinggi terhadap pelaku Bom Bali I masih dianggap sah dan memiliki kekuatan hukum tetap.

Putusan Mahkamah Konstitusi tidak dapat dijadikan sebagai alat bukti baru, karena pada putusan tingkat pertama dan tingkat kedua, ketentuan retroaktif dalam undang-undang terorisme belum dinyatakan tidak mengikat oleh Mahkamah Konstitusi, fakta hukum yang digunakan oleh pengadilan merupakan fakta pada saat undang-undang masih berlaku, ketika Mahkamah Agung mengkaji keberlakuan undang-undang pengadilan berdasarkan undang-undang tersebut, tidak mungkin ditemukan adanya kesalahan dalam pengajuannya.

Aturan lain selain daripada Undang-Undang Nomor 15 Tahun 2003 tidak dapat menjerat mereka yang tidak terlibat langsung dengan kasus Bom Bali I. Ini berarti tidak ada aturan yang mengatur soal networking, yakni mereka yang mengetahui pelaku terorisme tapi tidak melaporkan atau orang yang menyembunyikan atau melindungi mereka yang terkait dengan terorisme. Sehingga hal tersebut dirasa akan sangat menyulitkan pemerintah dalam memberantas terorisme.

Pada hari Kamis, tanggal 30 Agustus 2007 majelis hakim Mahkamah Agung yang diketuai oleh Iskandar Kamil, Djoko Sarwoko dan Baharuddin Qoudry, menyatakan putusannya menolak peninjauan kembali karena upaya hukum luar biasa yang mereka tempuh ditolak oleh Mahkamah Agung, maka eksekusi pelaksanaan hukuman mati bagi Ali Ghufron, Amrozi dan Imam Samudra divonis bersalah atas kasus bom bali I dan pidana mati Bom Bali I tetap dilaksanakan pada hari Sabtu, tanggal 8 November 2008 di Bukit Nirbaya, Cilacap, Jawa Tengah oleh Tim Eksekutor.

\section{KESIMPULAN}

Berdasarkan hasil penelitian yang telah dilakukan, maka kesimpulan dari penelitian ini adalah :

1. Instrumen hukum yang tidak ada sehingga tidak mampu untuk mengenakan hukum para pelaku teror Bom Bali I kala itu menyebabkan pemerintah tidak menggunakan asas legalitas yang terkandung di dalam KUHP Indonesia. Pemerintah Indonesia meyakini jika dengan mengaktifkan asas retroaktif untuk sementara waktu yang mengkhususkannya terbatas pada peristiwa terorisme bom bali I adalah upaya terbaik sebagai solusi atas kekosongan hukum. Indonesia mempunyai aturan khusus tentang terorisme, yaitu Perppu. Meski demikian, seperti yang telah dijelaskan dalam bab sebelumnya jika Perppu Nomor 2 Tahun 2002 yang mengaktifkan asas berlaku surut dalam Pasal 46 Perppu Nomor 1 Tahun 
2002 merupakan ketentuan yang lahir memang "sengaja” untuk dimatikan karena sejak awal telah mengalami sebuah kecacatan dalam pembentukan hukumnya.

2. Akibat hukum yang timbul setelah dikeluarkannya Putusan Mahkamah Konstitusi Nomor 013/ PUU-I/ 2003 memberikan dampak terhadap para pelaku Bom Bali I. Melalui putusannya, Mahkamah Konstitusi berusaha untuk mengembalikan cara kerja hukum pidana Indonesia ke jalurnya yang semula, meskipun begitu putusan Mahkamah Konstitusi tersebut tidak memiliki kemampuan untuk mengubah putusan-putusan hakim yang terdahulu, yaitu putusan Bom Bali I yang telah berkekuatan hukum tetap sebelum dibatalkannya UU Nomor 16 Tahun 2003 yang sebelumnya Perppu Nomor 2 Tahun 2002 karena putusan yang dihasilkan oleh Mahkamah Konstitusi dianggap sah dan mengikat sebagaimana dijelaskan dalam Pasal 58 UU Nomor 24 Tahun 2003.

\section{DAFTAR PUSTAKA}

Arief, Barda Nawawi. 1994. Kebijakan Legislatif dalam Penanggulangan Kejahatan dengan Pidana Penjara. Semarang: Ananta.

Firmansyah, Hery. 2011. Upaya Penanggulangan Tindak Pidana Terorisme di Indonesia. Jurnal Magister Hukum Vol. 23, No.2. Universitas Gadjah Mada Yogyakarta.

Hartono, Sunaryati. 1994. Penelitian Hukum Indonesia pada Akhir ke-20. Bandung: Alumni.

Jaya, Nyoman Serikat Putra. 2004. Pemberlakuan Hukum Pidana secara Retroaktif sebagai Penyeimbang Asas Legalitas dan Asas Keadilan (Suatu Pergeseran Paradigma dalam Ilmu Hukum Pidana). Pidato Pengukuhan Upacara Penerimaan Jabatan Guru Besar Ilmu Hukum Pidana. Universitas Diponegoro Semarang.

Mardenis. 2012. Pemberantasan Teorisme: Politik International dan Politik Hukum Nasional Indonesia. Jakarta: PT. Raja Grafindo Persada.

Rahayu, Sri. 2014. Asas Legalitas terhadap Penerapan Hukum dan Keadilan. Jurnal Inovatif Vol. VII, No.2. Universitas Jambi.

Republik Indonesia, Undang-Undang No. 1 Tahun 1946 tentang Peraturan Hukum Pidana.

Republik Indonesia, Undang-Undang No. 24 Tahun 2003 tentang Mahkamah Konstitusi.

Republik Indonesia, Undang-Undang No. 5 Tahun 2018 tentang Perubahan Atas Undang- Undang Nomor 15 Tahun 2003 tentang Penetapan Peraturan Pemerintah Pengganti Undang-Undang Nomor 1 Tahun 2002 tentang Pemberantasan Tindak Pidana Terorisme Menjadi Undang-Undang.

Ruba'I, Masrichin. 2001. Asas-Asas Hukum Pidana. Malang: UMM Press.

Sodarsono. 2007. Kamus Hukum, Cetakan Kelima. Jakarta: PT. Rineka Cipta. 
Supardjaja, Komariah Emong. 2008. Ajaran Sifat Melawan Hukum dalam Hukum Pidana Indonesia (Studi Kasus tentang Penerapan dan Perkembangannya dalam yurispudensi). Bandung: Alumni.

Usfa, A. Fuad dan Tongat. 2004. Pengantar Hukum Pidana. Malang: UMM Press. 